\title{
Articles
}

\section{The definition of criminal sanctions in the EU}

\author{
Jacob Öberg ${ }^{\star}$
}

\section{Introduction}

This Article reviews how we should define criminal sanctions in EU law. Defining what are 'criminal sanctions' is a long- standing issue of criminal law which has been debated for almost a century. ${ }^{1}$ The term 'criminal' is generally used by commentators and courts to refer to sanctions of a severe nature that are intended to punish rather than simply deter or compensate in contrast to civil or administrative sanctions. The distinctions have also been drawn as a matter of procedure. Criminal proceedings are, in contrast to civil proceedings, initiated by the government or by governmental authorities rather than by private parties. They entail a higher standard of proof, different rules of discovery and evidence. Criminal proceedings further trigger certain fundamental rights such as the right to counsel, the right to a fair trial and other procedural guarantees. ${ }^{2}$ It is further suggested that in order for a sanction to be considered criminal, it must involve having moral-social stigma attached. $^{3}$

While the problem of defining a criminal sanction is a very complex issue which could be subject for a whole dissertation ${ }^{4}$, the focus in this article is, however, on the definition of criminal sanctions in EU law. The debate on the proper meaning of 'criminal sanctions' has firstly received strong impetus in EU law, due to the newly gained competences of the Union in criminal law after the ratification of the Lisbon Treaty. ${ }^{5}$ According to Article 83 (1) and 83 (2) of the Treaty of the Functioning of the European Union (TFEU), the Union now has a competence to

\footnotetext{
${ }^{\star} \mathrm{PhD}$ Researcher at the European University Institute, Florence. E-mail: Jacob.Oberg@EUI.eu. Postal address: Villa Schifanoia, Via Boccaccio 121, 1-501 33 Firenze/Italy. An extended version of this contribution was presented at the advanced seminar on "Fundamental Rights in the European Union" on $13^{\text {th }}$ of March 2012 in Florence. Special thanks to Professor Giorgio Monti, EUI, for his support and constructive comments. I would also like to specifically thank the anonymous reviewer for his/her fruitful comments on the manuscript.

${ }^{1}$ See F. B. Sayre, 'Public Welfare Offenses', 33 COLUM. L. Rev. 55, (1933); H. L. Packer, The Limits of the Criminal Sanction, (Stanford University Press, 1968): J. C. Coffee. Jr., 'Does "Unlawful" Mean "Criminal"? : Reflections on the Disappearing Tort/Crime Distinction in American Law', 71 B. U. L. REV. 193, at p. 198, (1991).

${ }^{2}$ See Article 6 of the European Convention for the Protection of Human Rights and Fundamental Freedoms, 4 November 1950, ETS 5. ('ECHR', 'Convention') ; S. H. Kadish, 'Some Observations on the Use of Criminal Sanctions in Enforcing Economic Regulations', 30 U. CHI. L. Rev. 423, at p. 426,(1963); A. de Moor-van Vugt, 'Administrative Sanctions in EU Law', 5 (1) REVIEW OF EUROPEAN ADMINISTRATIVE LAW 5, at pp. 1115, 18-24, (2012).

${ }^{3}$ See K. Mann, 'Punitive Civil Sanctions: The Middleground Between Criminal and Civil Law', 1 O1 YALE L. J. 1795, at pp. 1808-1810, (1992); Coffee JR, supra n 1, at pp. 223-228; Kadish, supran 2, at p. 437.

${ }^{4}$ See P. Asp, EG: s sanktionsrätt (Iustus förlag, 1998).

${ }^{5}$ See A. Klip, European Criminal Law, (Intersentia, 2009), pp. 158-160.
} 
define criminal offences and impose criminal sanctions. The second reason for the fuelling of a debate on the meaning of criminal sanctions is related to the EU's envisaged accession to the European Convention of Human Rights ('ECHR' Convention). It is obvious that the EU would have to comply with the precepts of the Convention when it imposes sanctions falling within the scope of the Convention. In particular, it would need to adopt such procedural safeguards to conform to Article 6 of the Convention when they impose a sanction that can be properly defined as a criminal charge within the meaning of said provision. ${ }^{6}$

Given this brief background, it is evident that the issue of finding a definition of criminal sanctions in EU law is pressing. The purpose of this article is two-fold. First, the article aims to clarify and explain the distinction between the concept of criminal sanctions for the purposes of procedural guarantees and the concept of criminal sanctions for the purposes of EU competence in Article 83(2) TFEU. Secondly, the article intends to develop a proper concept of criminal sanctions that can be applied both to determine the Union' competence under Article 83(2) TFEU and also a definition that can be employed more generally to determine, for example, whether Member States indeed have complied with their obligations under EU law directives.

Having introduced the topic and the objectives of the article, we briefly account for some delimitations of the scope of the enquiry. The enquiry is limited to Article 83(2) TFEU. But why does the examination not also cover Article 83(1) TFEU? The main reason for choosing to discuss solely 83(2) TFEU in detail is that arguably all sanctions imposed under the competence of Article 83(1) are likely to be of a 'criminal' nature. The clear practice of the EU institutions under Article 83(1) TFEU is to impose directives prescribing imprisonment sanctions. ${ }^{7}$ It unequivocal that 'imprisonment', as argued below, is the prime example of 'criminal sanctions' both because of the harsh consequences relating to this sanction and because of the moral condemnation this sanction entails. ${ }^{8}$

Before bringing the introduction to a close, some words on the structure of the article are warranted.

The first part of the article deals with the discussion of the different functions of the concept of criminal sanctions in EU law. It accounts for the distinction between

\footnotetext{
${ }^{6}$ See P. Asp, Criminal Law Competence of the EU (Jure 2013), at pp. 63-64.

${ }^{7}$ See Article 5.3-4 of Proposal for a DIRECTIVE OF THE EUROPEAN PARLIAMENT AND OF THE COUNCIL on the protection of the euro and other currencies against counterfeiting by criminal law, and replacing Council Framework Decision 2000/383/JHA, Strasbourg, 5. 2. 2013, COM(2013) 42 final, 2013/0023 (COD), p. 15-16; See Article 9-10 of Proposal for a DIRECTIVE OF THE EUROPEAN PARLIAMENT AND OF THE COUNCIL on attacks against information systems and repealing Council Framework Decision 2005/222/JHA \{SEC (2010) 1122 final $\}\{$ SEC(2010) 1123 final $\}, \operatorname{COM}(2010) 517$ final, 2010/0273 (COD), p.15; See Article 4 of Proposal for a DIRECTIVE OF THE EUROPEAN PARLIAMENT AND OF THE COUNCIL on preventing and combating trafficking in human beings, and protecting victims, repealing Framework Decision 2002/629/JHA, Brussels, 29. 3. 2010, COM(2010)95 final, 2010/0065 (COD), at pp. 15-16; See Articles 3-6, 9 of Proposal for a DIRECTIVE OF THE EUROPEAN PARLIAMENT AND OF THE COUNCIL on combating the sexual abuse, sexual exploitation of children and child pornography, repealing Framework Decision 2004/68/JHA, Brussels, 29. 3. 2010, $\operatorname{COM}(2010) 94$ final, 2010/0064 (COD), at pp. 14-17.

${ }^{8}$ See D. M. Kahan, 'What do alternative sanctions mean?' 63 University of Chicago Law Review 593, at pp. 62124, 645, 649 and 652, (1996).
} 
the concept of criminal sanctions for the purposes of competence and the concept of criminal sanctions for the purposes of fundamental right guarantees. The second part of the article discusses the proper meaning of criminal sanctions in Article 83(2) TFEU and its general meaning in terms of Member States' obligations to implement EU law. In this regard, there will be an extensive discussion concerning the relevant criteria for determining whether a certain sanction is criminal or not. The third part of the article applies these criteria to the case of Union competition law fines, disqualification orders and individual fines where particular focus will be on the first mentioned category of sanctions. This part of the article also applies the criteria to recent legislative initiatives to consider whether the Union has complied with the proposed criteria. Finally, the article summarizes the findings of the examination.

\section{The different concepts of criminal sanctions in European Law}

It is argued that the question of defining criminal sanctions arises in two contexts. First, as a matter of competence and secondly, as a matter of determining what procedural safeguards the EU needs to implement to conform to the standards of the Convention. There are arguably two different concepts of criminal sanctions in EU law, one to decide the scope of the competence in Article 83 as well as Member States' obligations under EU law directives, and the other (concept), to decide on the scope of procedural safeguards. The concept of criminal sanctions fulfils different functions in those two contexts in order to resolve the problems of determining competences and the problem of determining the scope of fundamental rights protection.

In relation to the competence in Article 83(2) TFEU, we are interested in pinning down what characterizes criminal sanctions in relation to other noncriminal sanctions. The aim here is arguably to produce a concept of criminal sanctions which is appropriate to restrain the excessive use of EU powers. If the Union institutions go beyond the competences that were attributed to it by the founding Treaties or exercise its competence in a manner that unnecessarily interferes with the competences of the Member States, this will in the long run seriously harm both the formal and social legitimacy of the Union. In order not to excessively intrude on the Member State's sovereignty and to delimit the scope of the Union's competence under Article 83(2) TFEU, it is appropriate to have a constricted definition of criminal sanctions. Such a narrow definition will force the Union legislator to use another legal basis for quasi-criminal sanctions and noncriminal sanctions when it intends to adopt such sanctions. A sanction, e.g. imprisonment, which is not adopted on the basis of Article 83(2) TFEU and labelled as a 'non-criminal/administrative sanction', may, depending on the chosen definition of 'criminal sanctions', be of such serious, severe and punitive character that it is considered to be adopted on the wrong legal basis because of the lex specialis nature of Article 83(2). Whether a sanction is 'criminal' in an EU perspective 
decides whether the rules providing for specific EU criminal law competence in Article 83 TFEU must be used or whether competence can also be based on other articles of the Treaties. ${ }^{9}$ Furthermore, in terms of implementation of criminal law directives, the practice of the Commission to not state the relevant criminal penalty and only prescribe that Member States should impose 'proportionate, dissuasive and effective criminal penalties' make it material for Member States in order to comply with the Directives to ascertain the meaning of 'criminal sanctions. ${ }^{10}$ For this reason, there are also good reasons to seek a narrow concept in order to limit Member States' liability for breaches of EU law.

An objection to having a narrow concept of criminal sanctions in matters of competences and Member States' obligations is that there is a risk that procedural guarantees may be circumvented. It could be argued that we need a broader conception of 'criminal sanctions' which also includes sanctions which have, although not labeled as 'criminal sanctions' and although they are not of such nature that they communicate moral condemnation, such severe consequences for individuals that they call for criminal procedural guarantees. ${ }^{11}$

My response to these debates is that we can and should have two different concepts.

When constructing the concept of criminal sanctions in Article 83(2) TFEU and for determining Member States' obligations to implement such sanctions under EU directives, it is argued that the legitimacy of criminal law and the need to avoid over-criminalization calls for a narrow definition of criminal sanction. ${ }^{12}$ If individuals and the society are to have credibility in the criminal justice system, it is necessary that sanctions are not classified as criminal if they are not of such a severe nature that they express moral condemnation. The adverse effects of excessive criminalisation manifest themselves as inefficiency in legitimate regulatory enforcement, as unfairness in the application of criminal regulatory sanctions, and as a devaluation of the traditional criminal laws through a lack of respect for the criminal process. ${ }^{13}$ It is therefore justified to have a narrow definition of criminal sanctions for the purposes of determining the competence in Article 83(2) TFEU.

\footnotetext{
${ }^{9}$ See Asp, supra n 6, at pp. 63-64; S. Weatherill, 'Better Competence Monitoring', 30 ELR 23 (2005), at pp. 2426; See S. Peers, EU Justice and Home Affairs Law, (OUP, 2011), at pp.765-766 ; J. H. H. Weiler, 'Transformation of Europe', 100Yale Law Journal 2403, at pp. 2468-69, (1991).

${ }^{10}$ See Article 5 of DIRECTIVE 2008/99/EC OF THE EUROPEAN PARLIAMENT AND OF THE COUNCIL of 19 November 2008 on the protection of the environment through criminal law and Article 1 of amended DIRECTIVE 2009/123/EC OF THE EUROPEAN PARLIAMENT AND OF THE COUNCIL of 21 October 2009 amending Directive 2005/35/EC on ship-source pollution and on the introduction of penalties for infringements; Article 6 of Proposal for a DIRECTIVE OF THE EUROPEAN PARLIAMENT AND OF THE COUNCIL on criminal sanctions for insider dealing and market manipulation, $\operatorname{COM}(2011) 654$ final.

${ }^{11}$ Asp, supra note 4, 361

${ }^{12}$ See D. Thornburgh, 'The Dangers of Over-Criminalization and the Need for Real Reform: The Dilemma ofArtificial Entities and Artificial Crimes', 44 Am. Crim. L.Rev. 1279, at p. 1279, (2007); E. Luna, 'The Overcriminalization Phenomenon', 54 American University Law Review 703, (2005).

${ }^{13}$ See Luna, supra note 12, at pp. 732-741; Thornburgh, supra note 12, at pp. 1280, 1283-1284. See J. S Baker Jr., 'Measuring the Explosive Growth of Federal Crime Legislation', Federalist Society for Law and Public Policy Studies, May 2004, 10, at pp. 28-30. Available at http://www.fed-soc.org/doclib/20080313_CorpsBaker.pdf.
} 
Secondly, there is a broader concept of 'criminal charge' in EU law that require Member States and the EU legislator to implement procedural guarantees when they implement sanctions falling within the scope of Article 6 ECHR. The concept of 'criminal sanctions' fulfil a different function within the context of fundamental rights guarantees. In respect of this context, we are mainly interested in ensuring that Member States and the EU do not undermine procedural safeguards for individuals by de-criminalizing certain behaviours. In order to achieve this aim, we need a broader concept of 'criminal' sanction than the one discussed above. ${ }^{14}$ This broader concept has been developed by the European Court of Human Rights (the 'Strasbourg Court') which has been called on to assess the meaning of criminal sanctions for the purposes of deciding on the scope of procedural guarantees in Article 6 of the Convention. The Strasbourg Court has elaborated independent criteria which basically says that the Strasbourg Court and national courts in convention states shall consider three criteria when determining whether there is a criminal sanction; i) the classification in the national legal system; ii) the nature of the offence; iii) the severity of the potential penalty which the person concerned risks incurring. ${ }^{15}$ The concept of criminal sanction has, within this context, essentially been developed to determine whether the accused should have minimum fundamental rights. In this regard, it appears that the Strasbourg Court have taken a broad stance to decide on what a criminal sanction is, not being restricted by the national definition of 'criminal sanctions', in order to ensure that the rights guaranteed by Article 6 ECHR are not compromised. ${ }^{16}$ It is evident that the Strasbourg Court, by adopting this broad concept of criminal charge, has pursued a judicial policy of avoiding de-criminalisation with an ensuing repressiveness and undermined procedural guarantees. ${ }^{17}$

It is arguably evident that the Strasbourg Court uses a concept of 'criminal sanctions' that is broader than the one used in an EU context for the purposes of determining competence matters. Sanctions falling within the definition of 'criminal charge' under Article 6 ECHR do not necessarily fall within the concept of criminal sanctions for the purpose of EU competence. This means that the EU, when adopting sanctions that are considered as 'criminal' pursuant to the case law of the Strasbourg Court, is under an obligation to ensure that the safeguards attached to the imposition of such sanctions are respected. This broad definition of 'criminal charge' entails that several administrative sanctions currently used within the EU context, such as competition law fines, could be considered as 'criminal' under

\footnotetext{
${ }^{14}$ See Asp, supra n 6, at pp. 59-60.

${ }^{15}$ See Engel and Others v. the Netherlands, judgment of 8 June 1976, Series A no. 22, pp. 34-35, paras. 82-83. See the impressive analysis of this case-law by M Delmas Marty: 'La matière pénale au sens de la Convention européenne des droits de l'homme, flou du droit pénal', in Rev. sc. crim., 819, (1987).

${ }^{16}$ See De Cubber v. Belgium, judgment of 26 October 1984, Series A 86, at para. 32.

${ }^{17}$ See ECHR, Key case-law issues, COMPATIBILITY RATIONE MATERIAE, ARTICLE 6, (NOTION OF “CRIMINAL CHARGE), para 3; Öztürk v. Germany, judgment of 21 February 1984, Series A no. 73, p. 21, para 49; See Case C-210/00,Käserei Champignon Hofmeister GmbH \& Co. KG v Hauptzollamt Hamburg-Jonas,ECR [2002] p. I-6453, Opinion of Advocate General Stix Hackl, para. 39. see S. Mietinen, Criminal Law and Policy of the European Union (Routledge, 2013), at p. 2, 209-211; Delmas-Marty, supra n 15, at pp. 824-826.
} 
Article 6 ECHR. ${ }^{18}$ As an example, it is suggested that the EU can adopt administrative sanctions under Article 114 TFEU of the Treaties that are of a non-criminal nature in terms of the question of legal basis but is considered to be of a 'criminal' nature for the purposes of Article 6 of the Convention. ${ }^{19}$ The fact that the EU is bound by the Convention leads to the consequence that the EU and the Member States need to implement those guarantees despite the fact that the sanctions are not considered as 'criminal' for the purposes of Article 83(2) TFEU. ${ }^{20}$

It is practicable and justified to have two concepts of 'criminal sanction'; one for the purposes of EU competences and one for the purposes of fundamental rights guarantees. While sanctions such as individual fines or disqualification orders may not, as argued below, be 'criminal' for the purpose of Article 83 (2)TFEU, they may still be 'criminal' for the purposes of Article 6 ECHR, thus giving additional procedural protection for individuals and undertakings. Given that Member States still need to comply with the ECHR and provide for procedural guarantees under Article $6 \mathrm{ECHR}$ in cases of the imposition of administrative sanctions that are considered as criminal pursuant to the Strasbourg Court's case-law, there is no reason why there would be any practical problem with having two definitions of criminal sanctions. $^{21}$

Since the two different concepts fulfil different functions and have different purposes, it is, as such, difficult to use one of the concepts to determine the meaning of the other concept. For this reason, we have to be very cautious when using the case-law of the Strasbourg Court to determine the scope of the criminal sanction concept in Article 83(2) TFEU. ${ }^{22}$ In order to streamline the discussion, and in order to develop a more unambiguous distinction between 'criminal sanction' and noncriminal sanctions and to come up with some preliminary, although incomplete, conclusions of the concept of criminal sanctions in EU law, the rest of the article will focus on reviewing the concept of criminal sanctions in Article 83(2) TFEU and the scope of the Member State's obligations to implement EU criminal law directive.

A novel and developed definition of criminal sanctions have at least two benefits. First, more elaborated criteria will facilitate in deciding whether the Union legislator acted on the correct legal basis and had the competence to adopt a certain sanction under Article 83(2) TFEU. Secondly, it will provide a more substantive basis for determining the meaning of criminal sanctions in order for the Commission and the Court of Justice to assess whether a Member State has breached the Treaty by not imposing 'criminal sanctions'.

\footnotetext{
${ }^{18}$ See Delmas-Marty, supra n 15, at pp. 851-52; C. Harding, European Community Investigations and Sanctions, (Leicester University Press, 1993), at p. 7, 138-140.

${ }^{19}$ See Asp, supran 6, at p. 60, 62.

${ }^{20}$ It appears from Bonda (C-489/10, Bonda, nyr, judgment of the Court of Justice of $5^{\text {th }}$ June 2012, paras. 36-45) that this is the approach taken by the Court of Justice.

${ }^{21}$ See Asp, supra n 4, 394-395.

${ }^{22}$ See, however, Andre Klip, which seems to believe that the Strasbourg Court's approach should also be guidance for the definition adopted in EU law of criminal sanctions (A Klip, European Criminal law, (Intersentia, 2012), at pp. 169-171).
} 
Having discussed the purpose and functions of the concept of 'criminal sanctions', it is time to move on with the construction of a concept of 'criminal sanctions' for the purposes of defining the competence in Article 83(2) TFEU.

\section{Analysis of the meaning of 'criminal sanctions' in Article 83(2) TFEU}

This section provides an account of the Court's criteria of determining the concept of 'criminal sanctions' in EU law. It is contended that, because the Court's criteria are insufficient and incomplete, a more refined definition is needed of the concept of 'criminal sanctions' in EU law.

\section{a) The Court's case-law on the meaning of criminal sanctions in EU law- insufficient and unworkable criteria}

The Union Courts have been compelled to assess the meaning of 'criminal sanctions' within the competence context. In this respect it should be noted that the legal terminology in Union law implied, prior to the ratification of the Lisbon Treaty, that there was assumedly a clear-cut distinction between 'criminal' and administrative sanctions given the limited criminal law competences that the Community institutions had in the framework of the First Pillar. ${ }^{23}$ This has triggered the Union courts to rule, on several occasions, on whether certain sanctions imposed were of a 'criminal' nature or not.

It transpires from the case-law of the Union Courts, that there are no refined and elaborated criteria for defining 'criminal sanctions'. The contours of the power seem to be decided on a case-by-case basis without any serious theoretical foundation. The context of the case-law have mainly been concerned with the issue of claims from the applicants that the Union sanction has been of a 'criminal' nature and thus outside the competence of the Union. ${ }^{24}$ Many cases concerned sanctions within the field of the Common Agricultural Policy (CAP) such as surcharges, forfeiture of deposits and exclusion from a specific benefit. ${ }^{25}$ Some cases have concerned competition law fines. ${ }^{26}$ None of these cases were really forcing the Court of Justice to explicitly develop a theory of what is a 'criminal' sanction as most of these cases could be decided in a straightforward manner as not involving

\footnotetext{
${ }^{23}$ See K. Ligeti, 'European Criminal Law: Administrative and Criminal Sanctions as Means of Enforcing Community Law', 41 Acta Juridica Hungarica 199, at pp. 199-200, (2000).

${ }^{24}$ See Asp, supra note 4, 350 .

${ }^{25}$ See C-11/70, Internationale Handelsgesellschaft mbH v Einfuhr- und Vorratsstelle für Getreide und Futtermittel, [1970] ECR 1125; Case C-25/70, Köster, [1970] ECR 1161; C-117/83, Könecke, [1984] ECR 3291 at p. 3304; Case 240/ 90, Germany vs. Commission [1992] ECR 1-5383; C-273/90, Meico-Fell v Hauptzollamt Darmstadt, [1991] ECR I05569; C-210/00, Käserei Champignon Hofmeister, supra n 17; C-62/06,ZF Zefeser, [2007] ECR p. I-11995.

${ }^{26}$ See T-83/91 Tetra Pak, [1994] ECR II-755. As concerns competition law fines, the Union's competence to adopt criminal sanctions has not been questioned to any larger extent, due to the unambiguous Treaty provisions and Article 23(5) of Regulation 1/2003 (See Council Regulation (EC) No 1/2003 of 16 December 2002 on the implementation of the rules on competition laid down in Articles 81 and 82 of the Treaty Official Journal L 1, 04. 01. 2003, pp.1-25, 'Regulation 1/2003'), stating that competition law fines shall not be of a criminal nature (See Asp, supra note 4, at pp. 345-346).
} 
'criminal' sanctions. ${ }^{27}$ In terms of forfeiture sanctions, the Court of Justice has emphasised that the only purpose of these is to guarantee that the voluntarily assumed obligation is fulfilled. ${ }^{28}$ Given that this does not have a punitive purpose but only a preventive and compensatory purpose, it cannot constitute a criminal sanction. ${ }^{29}$ Penalties laid down in rules of the CAP, such as the temporary exclusion of an economic operator from the benefit of an aid scheme, are not of a criminal nature. The Court has held that the rules breached are aimed solely at economic operators who have freely chosen to take advantage of an agricultural aid scheme. The penalty imposed in the event of non-compliance with those requirements constitutes a specific administrative instrument forming an integral part of the scheme of aid and intended to ensure the sound financial management of public funds of the EU. ${ }^{30}$

An evaluation of the current case-law of the Union Court reveals the lack of a clear conception of what a 'criminal' sanction is. It is seemingly unclear what criteria the Union Courts take into account when it decides on the meaning of 'criminal' sanctions. While some Advocate Generals have endeavoured to justify the adoption of the moral condemnation criteria, the Court has, to a large extent, remained silent on what specific criteria it considers. ${ }^{31}$ Due to the criticism raised against the lack of a general approach from the Union Courts on the issue of defining 'criminal' sanctions, it would appear important to rethink the meaning of criminal sanctions in EU law and develop independent criteria. We can commence our examination on fresh grounds departing from a sound theoretical understanding of the nature of criminal sanctions, as well as an understanding of the judicial construction of the concept.

\section{b) Relevant criteria for determining the 'criminal' nature of EU sanc- tions}

\section{aa) The legislator's labelling of something as a 'criminal' sanction}

First, a basic starting point for any discussion on the definition of criminal sanctions is the link to the labelling of something as a 'criminal offence'. ${ }^{32}$ This

\footnotetext{
${ }^{27}$ See C-11/70, Internationale Handelsgesellschaft $m b H v$ Einfuhr- und Vorratsstelle für Getreide und Futtermittel, supra note 25, para. 18. ECR 1125. The Court held in this case that the system of deposits could not be equated with a penal sanction, since it was merely the guarantee that an undertaking voluntarily assumed will be carried out. See also C- 240/90, Germany v Commission, supra note 25, paras. 25-26; C- 273/90, Meico-Fell v Hauptzollamt Darmstadt, supra note 25, paras. 9 and 12; T-83/91, Tetra Pak, supra note 26, para. 235.

${ }^{28}$ See C-117/83 Könecke, supra note 25, para. 14.

${ }^{29}$ See C-25/70, Köster,supra note 25, Opinion of Advocate General A. Dutheillet de Lamothe, p. 1142.

${ }^{30}$ See C-489/10, Bonda, supra n 20, paras. 28-30.

${ }^{31}$ See C-240/90, Germany v Commission, supra note 25, Opinion of Advocate General Jacobs, para. 11; See C273/90, Meico-Fell v Hauptzollamt Darmstadt, supra note 25, Opinion of Advocate General Van Gerven, para. 10; C440/05, Commission v Council,[ 2007] ECR p. I-9097, Opinion of Advocate General Mazak, paras 67-71; C-62/06, ZF Zefeser, supra note 25, Opinion of Advocate General Trestjenak, paras. 55-57.

${ }^{32}$ See Packer, supra note 1, at pp. 18-19; Asp, supra note 4, at pp. 354, 363-365. This is consistent with the approach adopted by the European Court of Human Rights according to the Engels criteria, see Key case-law issues, supra note 17, paragraph 5; S. P Green, 'Why It's a Crime to Tear the Tag Off a Mattress: Over-criminalization and the Moral Content of Regulatory Offenses', 46 Emory L. J. 1533, at pp. 1542-43, (1997).
} 
argument envisages that if the Union states that certain behaviour, e.g. infringements of competition rules, is a 'criminal' offence, any sanction that follows would have to be 'criminal' sanctions. ${ }^{33}$ What makes something 'criminal' is whatever that the legislator declares formally and authoritatively to be 'criminal'. ${ }^{34}$ If EU legislation requires the Member States to introduce rules that according to their own law would be considered criminal in character, we are certainly dealing with 'criminal' sanctions. ${ }^{35}$ It is therefore relevant to consider whether the penalty imposed can be found in national criminal laws. ${ }^{36}$

Nevertheless, most commentators agree that there is something more behind the definition apart from legislative authorization. There are arguably independent standards for judging whether something should be labelled as a 'criminal' sanction. ${ }^{37}$ The label cannot be decisive as it would then be possible for the EU to circumvent procedural guarantees. The EU should not be allowed to by-pass constitutional challenges prompted by the absence of procedural safeguards by moving cases out of criminal courts by illegitimate de-criminalization. Assume, for example that the EU would require the introduction of rules, making certain conduct, for example, a special type of cyber-attacks, subject to penalties consisting of imprisonment from 48 to 96 months. Even if such an instrument contained a rule stating that the rules transposed should not be considered to be of a 'criminal' nature, it seems obvious that the penalty in question must be regarded as being of a 'criminal' nature in terms of competences. ${ }^{38}$

\section{bb) The relevance of the procedure in question for determining the nature of a sanction}

Secondly, it is submitted that the procedure matters in terms of the definition. Whether the imposition of the sanction is linked to an administrative or criminal procedure and whether the procedure is associated with strong procedural guarantees for the defendant can influence the determination of the legal nature of the sanction. ${ }^{39}$ It is particularly relevant to consider whether the sanction at issue can be imposed by an administrative authority or must be imposed by a Court of law. If the sanction can only be imposed by a Court of law, this suggests that what is at stake is a 'criminal' sanction. Conversely, if the sanction can be imposed

\footnotetext{
${ }^{33}$ See Asp, supra note 4, 364-365; G. Williams, Textbook of Criminal Law, (Stevens and Sons, 1978), at p. 16; Smith and Hogan, Criminal Law (Butterworths, 2002), at p. 17; A. Ashworth, Principles of Criminal law (OUP, 1995), at pp. 1-2; See N. Haekkerup, Controls and Sanctions in the EU Law, (Djoef Publishing, 2001), at p. 158; H. L. A. Hart, 'The Presidential Address: Prolegomenon to the Principles of Punishment', 60 Proceedings of the Aristotelian Society 1, at p. 4. (1959).

${ }^{34}$ See Packer, supra note 1 at pp.18-19; See R. Dagger,' Republicanism and the foundations of criminal law', in RA Duff and S. P. Green, Philosophical Foundations of Criminal Law, (OUP, 2011), at pp. 50-51.

${ }^{35}$ See Asp, supran 6, at p. 67.

${ }^{36}$ See Haekkerup, supra n. 33, at p. 161.

${ }^{37}$ See Dagger, supra n 34, 49.

${ }^{38}$ See Asp, supra n 6, at p. 66; See Wilson, Central Issues in Criminal Theory, (Hart, 2002), at p. 44.

${ }^{39}$ See Article 6 and 7 of the ECHR; Asp, supra note 4, at p. 363; See Harding, supra n 17, at p. 7; Hart, supra n 33, at p. 4 .
} 
by an administrative authority, this rather suggests that it is a non-criminal sanction. $^{40}$

It is further relevant to consider whether proceedings are brought by prosecutors or by a private person. In civil actions, it is normally the case that the person must be directly affected by the wrong, i. e. the persons injured, while this is not the case in criminal proceedings. ${ }^{41}$ Furthermore, civil actions may be discontinued at any point while this is not the case for criminal proceedings. ${ }^{42}$ This criterion can certainly be used to exclude certain sanctions from the 'criminal' sanction characterisation. Punitive damages, although they have retributory features by not only compensating the victim but also punishing the offender, is arguably not of a 'criminal' nature because this sanction is not imposed by the prosecutor on behalf of the society. The right to pursue actions for punitive damages is a right that society confers to the injured party, who alone can exercise it freely. Since the procedure for imposing this sanction is private in nature, we cannot consider it as a 'criminal' sanction. $^{43}$

It is also relevant to consider the procedural guarantees attached to the imposition of the sanction. If the procedures for imposing the sanction suggest that the imposition of the sanction at issue do not entail full procedural guarantees and if the sanction is imposed by an administrative authority, this indicates that they are not of a criminal nature. Criminal procedures tend to have stronger procedural protections, designed to avoid false convictions, while enforcement authorities tend to have stronger investigative powers. In particular, in criminal enforcement systems the adjudicative function is always separated from the investigative and prosecutorial functions. $^{44}$

However, if the procedural guarantees are given a decisive importance for determining the legal nature of a sanction, this may lead to some serious adverse effects for the legal protection of individuals. It may be inappropriate to construct a concept of 'criminal' sanctions, which entail that the legislator, by means of removing procedural guarantees, can sustain the conclusion that a certain sanction is not criminal, even if the sanction has severe consequences for the individual. It is thus not suitable to draw decisive conclusions from the procedural regulation as to whether a specific sanction is criminal or not. ${ }^{45}$

\footnotetext{
${ }^{40}$ See Benham v. the United Kingdom, judgment of 10 June 1996, Reports of Judgments and Decisions 1996 III, para. 56; Green, supra note 32, at p. 1543; See Williams, supra n. 33, at pp. 14-17; Haekkerup, supra n 33, at p. 161.

${ }^{41}$ See Smith and Hogan, supra n 33, at p. 16.

${ }^{42}$ See Williams, supra n 33, at p. 15; Smith and Hogan, supra n 33, at p.16, 19-20.

${ }^{43}$ See E Durkheim, The Division of Labor in Society, (English translation, Free Press, 1984), at pp. 50-51.

${ }^{44}$ See W. P.J. Wils, 'Is criminalisation of EU Competition law the answer?', paper presented at the Amsterdam Centre for Law and Economics (ACLE) Conference Remedies and Sanctions in European Competition Policy (Amsterdam, 17-18 February 2005), in World Competition: Law and Economics Review, Vol. 28, No. 2, June 2005 and in Remedies and Sanctions in Competition Policy: Economic and Legal Implications of the Tendency to Criminalize Antitrust Enforcement in the EU Member States, edited by K. J. Cseres, M. P. Schinkel, F. OW Vogelaar, (Edward Elgar Publishing, 2006), at p. 6; See Asp, supra note 4, at p. 359; Green, supra note 32, at p. 1543.

${ }^{45}$ See Asp, supra note 4, 360.
} 


\section{cc) Principles of liability as a characteristic of a criminal sanction}

Thirdly, it is generally argued that a characteristic feature of criminal sanctions is that they should only be imposed after the determination of guilt. ${ }^{46}$ The principle of guilt or culpability is founded primarily on considerations concerning legal protection of the individual and with fair attribution of guilt. ${ }^{47}$ The committal of a criminal offence usually requires that the prohibited act be committed with a guilty state of mind not by mere negligence. ${ }^{48}$ Criminal sanctions are concerned with establishing a normative connection between an individual and a certain act and its consequences. ${ }^{49}$ In particular, it seems difficult to classify a sanction as 'criminal' if it is imposed for an offence which the offender is not responsible for. ${ }^{50}$ This is based on the concern that 'criminal law' will not be considered by society as a moral message communicating blame and condemnation if 'criminal sanctions' can be imposed under strict liability regimes. This may threaten the whole legitimacy of 'criminal law' as a social-ethical instrument to govern human behaviour. ${ }^{51}$

Some prudence is also warranted when linking the definition of criminal sanctions to liability principles. If the legislator by removing the principle of guilt for determining liability for an offence, by prescribing strict liability, is able to reclassify something as not being a criminal sanction, the consequence will be the same as the one considered above in relation to procedural guarantees. The legislator may, by having strict liability, impose severe and repressive sanctions against an individual without any serious legal protection for the individual. This lack of legal protection can only be supported in cases of less serious sanctions of an administrative nature. ${ }^{52}$

\section{dd) Deterrent and punitive purpose of the sanction}

Fourthly, the question whether a sanction constitutes a 'criminal' sanction should also be determined in the light of the 'deterrent and punitive' character of the sanction. 'Criminal' sanctions must involve both a preventive function and a deontological dimension. If something is to be defined as a 'criminal sanction' it must first communicate disincentives for individuals to engage in criminal behaviours. Without recourse to the simple idea that the criminal law sets up standards of behaviour

\footnotetext{
${ }^{46}$ See C-240/90, Germany v Commission, supra note 25, Opinion of AG Jacobs, para. 11; Green, supra note 32, at pp. $1547-1549$.

${ }^{47}$ See Haekkerup, supran 33, at pp. 158, 161; See Asp, supra n 6, at p. 67.

${ }^{48}$ See Wils, supra n 44, at p. 6; A Ashworth, Sentencing and Penal Policy (Weidenfeld and Nicholson, 1983), at pp. 150-156.

${ }^{49}$ See P Asp, 'Blacklisting Sanctions and Principles of Criminal Law' in EU Sanctions: Law and Policy Issues Concerning Restrictive Measures, (I. Cameron, ed. ) (Intersentia, 2013), at p. 133, 135-136.

${ }^{50} \mathrm{Ibid}$, at p. 132.

${ }^{51}$ See H. M. Hart, Jr., 'The Aims of the Criminal Law', 23 LAW \& CONTEMP. PROBS. 401, at pp.422-25 (1958); R. M. Perkins, 'Criminal Liability Without Fault: A Disquieting Trend', 68 IOWA L. REV. 1067, at pp. 1079-81, (1983); Kadish, supra n 2, at p. 444, 448-49.

${ }^{52}$ See Sayre, supra note 1, at p. 68, 70, 72; Kadish, supra note 2, at p. 442.
} 
to encourage certain types of conduct and discourage others, we could not to distinguish a criminal fine from a tax on a course of conduct. ${ }^{53}$

However, a sanction which only has a deterrent character cannot be characterised as a 'criminal' sanction. ${ }^{54}$ Criminal sanctions must also have a punitive dimension. The imposition of criminal sanctions has a social dimension in how it is understood by society and involves a moral appeal that cannot be reduced to a mere disincentive. The punitive purpose is often reflected in equilibrium between the gravity of the offence and the punishment. Sanctions that reflect what an offender deserves to suffer characterise a punitive purpose. While some sanctions have a deterrent character, such as private damages, such sanctions should not be considered as criminal sanctions because, among other reasons, the remedy is typically compensatory rather than punitive. ${ }^{55}$

\section{ee) The severity of the penalty}

Although the previously listed criteria have some relevance to determine the criminal nature of sanctions, it appears that the final two criteria, severity and the moral condemnation criteria are undoubtedly the most important criteria for determining the nature of the sanction. First, we discuss the 'severity' criterion.

One of the core characteristics for determining whether a sanction has a 'criminal' character, together with the moral condemnation criteria, is the rigour of the potential penalty. ${ }^{56}$ A sanction of a 'criminal' nature must arguably involve pain or other unpleasant consequences. ${ }^{57}$ This is a key criterion for determining the nature of the sanction given the fact that the severities of the penalty normally warrant the criminal procedural guarantees. Not all unpleasant consequences or pains inflicted on individuals by the state should, however, be classified as criminal sanctions. While deportation of aliens and expatriation of individuals are sanctions which have serious consequences for individuals, they are arguably not sufficiently serious to be classified as 'criminal' sanctions. ${ }^{58}$

\footnotetext{
${ }^{53}$ See Hart, supra n 33, at p. 6; See Haekkerup, supra note 33, at p. 158; See A.P. Simester \& A. Von Hirsch, Crimes, Harms and Wrongs- On the Principles of Criminalisation, (Hart, 2011), at pp. 5, 7-10; Asp, supra note 4, p. 363; Delmas-Marty, supra n 15, at p. 837. This is also recognized by the European courts: See Öztürk v. Germany, supra note 17, para. 53; Bendenoun v. France, judgment of 24 February 1994, Series A no. 284, para. 47; C-240/90, Germany v Commission, supra note 25, paras. 25-26; C-117/83, Könecke, supra note 25, para. 14.

${ }^{54}$ See Asp, supra note 4, at p. 360; C-240/90, Germany v Commission, supra note 25, Opinion of Advocate General Jacobs, para. 11.

${ }^{55}$ See A. Harel, 'Why Only The State May Inflict Criminal Sanctions: The Case Against Privately Inflicted Sanctions', 14, Legal Theory 113, (2008), p. 116; See Durkheim, supra n 43, at pp. 46-47.

${ }^{56}$ See Ezeh and Connors v. the United Kingdom, judgment of $9^{\text {th }}$ October 2003 (Grand Chamber), application nos. 39665/98 and 40086/98, ECHR 2003-X, para. 86; See Dubus SA v France, Application, Judgement of $11^{\text {th }}$ June 2009, application no. (5242/04), para 38; See C-240/90, Germany v Commission, supra note 25, paras. 25-26; C-273/ 90, Meico-Fell v Hauptzollamt Darmstadt, supra note 25, Opinion of Advocate General Van Gerven, para. 10; C-62/ 06,ZF Zefeser, supra note 25, Opinion of Advocate General Trestjenak, paras. 55-57;M.Kaiafa-Gbandi, 'The Importance of Core Principles of Substantive Criminal Law for a European Criminal Policy Respecting Fundamental Rights and the Rule of Law' 1 EuCLR 7, at p. 7, (2011); Green, supra note 32, at p. 1544; see Harding, supra n 17, at p. 7 .

${ }^{57}$ See Hart, supran 33, at p. 4; Wilson, supra n 38, at p. 44.

${ }^{58}$ See A Harel, supran 55, p. 116.
} 
Intrusive or burdensome sanctions that entail serious interference with people's lives are good candidates for the 'criminal' sanction label. It is inevitable to highlight the hard treatment and the intrusiveness of a criminal sanction. Sanctions that are so severe that it entails a deprivation of liberty or sanctions that can be replaced by deprivation of liberty, are typical examples that require a criminal label. While fines arguably can be either criminal or civil or administrative, there seems to be no doubt that imprisonment, due to its severity, qualifies as a 'criminal' sanction. ${ }^{59}$ First, imprisonment sanctions, which are enforced in order to address serious violations of basic interests in society, also constitute counterbreaches of inter alia the liberty those convicted. Secondly, the social-ethical denunciation inherent in imprisonment sanctions remains firmly attached to the convicted criminal long after the sentence has been served. Imprisonment sanctions are the strongest formal social condemnation that society can impose on one of its citizens. An imposition of a criminal record means that the offender has been officially condemned as a wrongdoer and that an adverse formal statement has been made in relation to him. The imposition of custodial sentences may affect the wrongdoer's status in society as a whole and prevent him from engaging in several activities in his community. ${ }^{60}$

\section{ff) Moral and social stigma as a characterizing feature of the criminal sanction}

In addition to the severity criterion, it is proposed that the most important criterion for determining whether a sanction is of a criminal nature is whether it expresses, to some extent, social-ethical condemnation. ${ }^{61}$ Criminal sanctions are generally distinguished from other sanctions by its communicative function and the fact that criminal sanctions speak with a moral voice. The only feature common to criminal sanction crimes is that its imposition involves general universal censure by the average member of each society of certain clearly defined acts. ${ }^{62}$ A judgment that the committed offence deserves a 'criminal sanction' communicates that the behaviour is morally objectionable and that the addressee is a moral agent capable of considering the wrongfulness and not just the threat of adverse consequences as a reason to desist from doing the behaviour. Criminal sanctions convey and communicate a negative collective valuation from a wider social community that a certain act is a culpable wrongdoing. One of the defining features of 'criminal'

\footnotetext{
${ }^{59}$ See Asp, supra n 6, at pp. 66-68; See H.J. Schroth, Economic Offences in EEC Law, (Engel, 1983), at p. 3; DelmasMarty, supra n 15, at p. 826; Haekkerup, supra n 33, at p. 161; Wils, supran 44, at p. 5.

${ }^{60}$ See Kaiafa-Gbandi, supra n 56, at p. 7; A Ashworth, The Criminal Process-An Evaluative Study, (Clarendon Press, 1994), at pp.57-67, 296.

${ }^{61}$ See C-240/90, Germany v Commission, supra note 25, Opinion of Advocate General Jacobs, para. 11; C-440/05, Commission $v$ Council, supra note 31, Opinion of Advocate General Mazak, para. 67. The moral condemnation criterion is a very well discussed topic in philosophy and criminal law. The argument in its most popular form is expressed by Joel Feinberg; 'The Expressive Function of Punishment', in Doing and Deserving: Essays in the Theory of Responsibility, (Princeton University Press, 1970), at pp. 95-118; see also Hart, supra n 33, at p. 7 ; Simester and Von Hirsch, supra n 53 , at p. 4 .

${ }^{62}$ See Hart, Jr., supra note 51, at pp. 404-405.
} 
sanctions is that it has a stronger message-sending role than civil or administrative sanctions. ${ }^{63}$

The point with introducing moral condemnation as a characterising criterion is to ensure that there is conformity between the views of the society on what a 'criminal' sanction is and the legal definition of 'criminal' sanctions. The moral condemnation criterion can for example be used to single out imprisonment as a 'criminal' sanction. Imprisonment is a 'criminal' sanction both for what it symbolizes and for what is experienced or achieved by this measure. It expresses moral condemnation stronger and more unequivocally than any other sanction because of the value attached to liberty in our society. ${ }^{64}$

There are, nevertheless, some limitations on the use of moral condemnation as a criterion for defining 'criminal' sanctions. While a line between censuring and noncensuring sanctions can be drawn in abstracto, this distinction is not easy to apply for the purpose of drawing the scope of the concept of 'criminal' sanctions in Article 83 (2) TFEU. ${ }^{65}$ First, it is not always easy to derive what the law should be from the general consensus of society. Secondly, while there may be a relationship between social consensus and the definition of 'criminal' sanctions, this does not necessarily imply that it will always be possible to find such a consensus. ${ }^{66}$ Admitting this, it is still contended that this is a relevant criterion since it has been demonstrated by social science that it is possible to measure the public's view on whether a sanction expresses condemnation. ${ }^{67}$ Nevertheless, moral condemnation must be used in conjunction with other criteria to find out whether a specific sanction is of a 'criminal' nature.

\section{gg) Summary of the definition}

Based on the preceding analysis it can be argued that 'criminal sanction' is a definition which includes the following features: i) a prescription that the behaviour

\footnotetext{
${ }^{63}$ See S. L. Pilcher, 'Ignorance, Discretion and the Fairness of Notice: Confronting "Apparent Innocence" in the Criminal Law', 33 AM. CRIM. L. REV. 1, at pp. 34-39, (1995); Wils, supra n 44, at p. 6; See J. C. Coffee, Jr., 'Paradigms Lost: The Blurring of the Criminal and Civil Law Models-And What Can Be Done About It', 101 YALE L.J. 1875, at pp. 1876, 78 (1992);P. Arenella, 'Convicting the Morally Blameless: Reassessing the Relationship Between Legal and Moral Accountability', 39 U.C. L. A. L. REV. 1511, at pp. 1530, 1622 (1992); Asp, supra n 6, at pp. 66-67; See Ashworth, supran 33, at p.1; Wilson, supran 38, at p. 45; See Smith and Hogan, supra n 33, at p. 4; Haekkerup, supra n 33, at p. 161; See Simester and Von Hirsch, supra note 53, pp. 4-5, 11-12; See Durkheim, supra $\mathrm{n}$ 43, at pp. 33-42, 57.

${ }^{64}$ See Kahan, supra n 8, at p. 592-93, 620, 650; V. Tadros,' Criminalization and Regulation' in The Boundaries of the Criminal Law (edited by R. A. Duff, L. Farmer, S. E. Marshall, M. Renzo, and V. Tadros), (OUP, 2010), at p. 165; P. Whelan,'A Principled Argument for Personal Criminal Sanctions as Punishment under EC Cartel Law', 4(1) Competition Law Review 7, at p. 37, (2007); at p. 37; Wils, supra n 44, at pp. 38-39; See C-240/90, Germany v Commission, supra note 25, Opinion of Advocate General Jacobs, para. 11.

65 See Ashworth, supran 33, at pp. 42-47.

${ }^{66}$ See Green, supra note 32, at pp.1554-1555.; Asp, supra n 6, at pp. 64-65.

${ }^{67}$ See T. Sellin \& M. E. Wolfgang, The Measurement of Delinquency (Patterson Smith, 1978); F. T. Cullen, et al., 'The Seriousness of Crime Revisited: Have Attitudes Toward White Collar Crime Changed?', 20 CRIMINOLOGY 83, at pp. 88-91, 99 (1982); G. P. Waldo \& T. G. Chiricos, 'Perceived Penal Sanction and Self-Reported Criminality: A Neglected Approach to Deterrence Research', 19 SOC. PROBS. 522, at pp. 529-536 (1972); U. S. Dept. of Justice, Bureau of Justice Statistics, 'The National Survey of Crime Severity' (1985); See Green, supra note 32, at pp. 1555, 1564.
} 
is 'criminal', ii) the nature of the proceedings, iii) is imposed after a finding of guilt, iv) the deterrent and punitive purpose of the sanctions, v) the severity and seriousness of the sanctions that may follow from the the committal of an offence, vi) whether the sanction expresses a moral condemnation. Obviously, several requirements are linked to each other. For example, it can easily be argued that the deterrent and punitive purpose of a sanction (requirement iv)) can be determined with reference to the severity of the sanction (v)) and the condemnatory nature of sanctions (vi) is determined by the severity of the sanction (v).

It is necessary to make a common cumulative analysis of these factors to define whether a specific sanction is 'criminal' or not. In this regard, requirement v) and vi) are the most relevant criteria in this exercise since, according to theory and judicial practice, they express, in substance, the 'criminal' nature of the sanctions. It is argued that the severity of the sanctions considered in conjunction with its capacity to express moral condemnation can, in principle independently, distinguish 'criminal' sanctions from other non-criminal sanctions. The criterion of severity and moral condemnation becomes particularly important in 'hard' cases. Hard cases are those where we have to characterise severe sanctions which do not entail deprivation of liberty and where the sanction at issue is not labelled as a 'criminal' sanction.

It is clear, as argued above, that imprisonment falls within the definition of 'criminal' sanctions. ${ }^{68}$ Furthermore, criminal fines, conditional sentences, community service orders and probation orders likewise fall within this category. ${ }^{69}$ The reasons for this are numerous. First, all of those sanctions have very serious adverse effects for individuals. Secondly, it is argued that all these sanctions, imprisonment being the prime example, communicate moral stigma. Thirdly, all of these sanctions have a deterrent and punitive purpose. All of these sanctions, particularly imprisonment, have an individual and general deterrent effect insomuch as more than other sanctions, they provide a serious disincentive for individuals to not reoffend or for people in general to breach the rules in question. Fourthly, their imposition is related to the finding of guilt. ${ }^{70}$

\section{Application of the proposed criteria}

From the above, it is clear that the proposed definition fails to give any straightforward answer to the issue of defining a criminal sanction. The really tough

\footnotetext{
${ }^{68}$ See A Klip,' Definitions of harmonisation' in A. Klip and H. van der Wilt (eds.) Harmonisation and harmonising measures in criminal law (Edited by A. Klip and H. van der Wilt), (Royal Netherlands Academy of Science, 2002) Proceedings of the colloquium, Amsterdam, 13-14 December 2001. Available at: http://www.knaw.nl/Content/ Internet_KNAW/publicaties/pdf/20021103.pdf. See chapter 26 of the Swedish Criminal Code (SFS 1962:700) of 1962. English translation (Ds 1999:36) available at: http://www.government.se/content/1/c6/02/77/77/cb79a8a3. pdf.

${ }^{69}$ Green, supra note 32, at p.1543; R. M. Brown, 'Administrative and Criminal Penalties in the Enforcement of Occupational Health and Safety Legislation', 30OSGOODE HALL L. J. 691, at pp. 718-719, 730, 734 (1992).

${ }^{70}$ See the Swedish Government memorandum on sanctions in the field of social security and insurance; 'Sanktionsavgifter på trygghetsområdet' (SOU 2011:3), at p. 175. See also Chapter 25, 27, 28 and 36, Section of the Swedish Criminal Code, supra n 68; Sayre, supra note 1, at pp. 69-70.
} 
question remains as it is necessary to determine the legal nature of 'hard cases' of sanctions that do not traditionally belong to the criminal sphere, for example, disqualification orders, individual administrative fines and administrative fines against undertakings. Whereas the proposed definition needs to take into account the specific elements of the sanction in order to determine its nature, it is material to apply the definition to some selected examples to demonstrate its scope and practical application.

In this regard, it is appropriate to discuss the legal nature of three sanctions; Union competition law fines, disqualification orders and individual administrative fines. The reason for this selection is that all these sanctions are repressive and impose adverse consequences for individuals and undertakings on which they are imposed. Furthermore, they are normally considered as a serious alternative to imprisonment sanctions in order to ensure effective enforcement of Union policies. One could therefore say that these sanctions fall within the borderline between 'criminal sanctions' and 'administrative sanctions'.

The main focus and detailed discussion will concern competition law fines, given that this is the most relevant issue at this point of EU criminal law. The reason for this is that competition law fines is an existing sanction within EU law and thus not a theoretical example. Furthermore, the debate on the nature of the proceedings has been intense during recent years. ${ }^{71}$ Finally, and most importantly, the case of competition law fines is a case in point to demonstrate the approach to the delimitation in Article 83(2) TFEU that only sanctions that are of a very severe nature and express moral condemnation can be subject to the characterisation of criminal sanctions for the purposes of Article 83(2) TFEU.

\section{a) Union competition law fines}

\section{aa) The legal classification}

It should first be recognised that the application of the formal classification criteria to competition law fines, simply entail that there is no 'criminal' classification on a Union level. Article 23(5) of Regulation 1/2003 stipulates that decisions imposing, inter alia, sanctions for infringement, 'shall not be of a criminal law nature'. A contrario, this textual interpretation suggests that fines imposed are administrative in nature, and that the procedure and, in particular, the rules on evidence, are not, therefore, to be subjected to criminal standards. ${ }^{72}$

In this regard, it should, however, be recalled that the definition above does not attach any decisive importance to the classification of the Union legislator as to the

\footnotetext{
${ }^{71}$ See D. Slater, S. Tomas, S and D. Waelbroeck, 'Competition law proceedings before the European Commission and the right to a fair trial: no need for reform?', Global Competition Law Centre Working Papers Series, GCLC Working Paper 04/08, accessible at http://www.coleurope.eu/content/gclc/documents/GCLC\%20WP\%2004-08. pdf ; W.P.J. Wils, 'The Increased Level of EU Antitrust Fines, Judicial Review and the ECHR', 33 World Competition 5, (2010); F. Castillo De La Torre , 'Evidence, Proof and Judicial Review in Cartel Cases', 32(4) World Competition 505, (2009).

72 See Joined Cases C-189/02 P, C-202/02 P, C-205/02 P to C-208/02 P and C-213/02 P Dansk Rørindustri and Others v Commission [2005] ECR I5425, paras. 215 to 223.
} 
legal nature of the sanction at stake. Instead, it is necessary to adopt a substantive, rather than a formal approach when determining whether competition law fines are of a criminal nature. ${ }^{73}$ We therefore need to go beyond the definition in Regulation $1 / 2003$ and examine in detail whether fines imposed in the Regulation are considered criminal sanctions or not. ${ }^{74}$ The provision in Article 23(5) of Regulation 1/ 2003, stating that the fines are not of a criminal law nature, is not therefore determinative. $^{75}$

\section{bb) The nature of the proceedings}

There are good arguments concerning the nature of the proceedings suggesting that competition law fines are not of a 'criminal' nature. Analysing the other formal elements of the competition law procedure, it appears that competition law fines are not imposed by a Court of law but by the Commission. Furthermore, in terms of the nature of the proceedings, the Court of Justice has also on several occasions pointed out and confirmed, despite appeals from Advocate Generals to the contrary $^{76}$, that the procedure before the Commission is administrative in nature. ${ }^{77}$ The Commission is neither required to afford the undertaking concerned the opportunity to cross-examine a particular witness and to analyse his/her statements at the investigation stage which is a conventional feature of a criminal proceeding. ${ }^{78}$

Nevertheless, there are other contrasting arguments pointing to the 'criminal' nature of the proceedings and the sanction imposed. First, it may be argued that the Commission's power under the Treaty and Regulation 1/2003 to enforce the Union competition rules, suggests that the Commission acts as a prosecutor. ${ }^{79}$ The Commission has very strong investigative powers under Regulation 1 /2003 which are reminiscent of a prosecutor's powers. It may impose sanctions directly on undertakings, investigate premises of the firms and other premises of company directors, interview responsible individuals and take witness statements. ${ }^{80}$ It has also been argued that the substance of the competition law procedures broadly exhibit the

\footnotetext{
${ }^{73}$ See Deweer v. Belgium,judgment of 27 February 1980, Series A no. 35, para. 44; C- 273/90, Meico-Fell v Hauptzollamt Darmstadt, supra note 25, Opinion of Advocate General Van Gerven, para. 10.

${ }^{74}$ See however Wils (supra note 44, at p. 11) which takes for granted, without any justification apart from the textual support, that the definition in Article 23(5) of Regulation 1/2003 is decisive for the legal classification of competition law fines.

${ }^{75}$ See J. Flattery, 'Balancing Efficiency and Justice in EU Competition Law: Elements of Procedural Fairness and their Impact on the Right to a Fair Hearing', 7(1) CLR, 53, at p. 77, (2010); Asp, supra note 4, at p. 365; M. Zuleeg, 'Criminal Sanctions to be Imposed on Individuals as Enforcement Instruments in European Competition Law', 2001 EUI Competition Law and Policy Workshop/Proceedings, at p. 2. Available at: http://www.eui.eu/RSCAS/ Research/Competition/2001/4-zueleeg.pdf.

${ }^{76}$ Case T-7/89 Hercules Chemicals v Commission [1991] ECR II- 1711, Opinion of Advocate General Vesterdorf, para I.3; Case C-185/95 P, Baustahlgewebe GmbH v EC, [1998] ECR I-8417, Opinion of Advocate General Léger, para 31.

77 See Case T- 99/04, AC-Treuhand v Commission, [2008] ECR II-1501, para 113; Joined Cases C 204/00 P, 205/ 00 P,Aalborg Portland A/S v Commission (Cement),[2004] ECR I-00123, para 200; Joined Cases T-25,103-104/95, Cimenteries CBR v. Commission, [2000] ECR II-491, paras 717-718.

${ }^{78}$ See Joined Cases C 204/00 P, 205/00 P,Aalborg Portland A/Sv Commission (Cement), supra note 77, para 200.

${ }^{79}$ See Benham v. the United Kingdom, supra note 40, para 56.

${ }^{80}$ See Article 7, 9, and in particular Articles 17-21 and 23 of Regulation 1/2003, supra n 26.
} 
characteristics of a criminal law case. The parties' submissions in competition law can be more easily understood with the help of the terminology and concepts used in criminal law and procedure. ${ }^{81}$ There are also principled arguments for a 'criminal' classification. The need to ensure procedural guarantees for undertakings and individuals accused of competition law infringements and the need to ensure Union fundamental rights such as the rule of presumption of innocence, the principle of legality and ne bis in idem principle favours criminal classification. ${ }^{82}$

\section{cc) The deterrent and punitive nature of the sanctions}

In terms of the deterrent nature of the sanction at stake, there are some arguments pointing in favour of the criminal classification. First, it has been asserted that since competition law fines are of and are intended to be of a dissuasive nature, this favours the "criminal' classification. ${ }^{83}$ Secondly, it is suggested that there has been a 'criminalization' of competition law sanctions in recent years in light of the huge fines the Commission may legally impose, in some cases exceeding the billion euro mark. ${ }^{84}$ Fines are argued to have a repressive and deterrent purpose, thus justifying a classification as criminal sanctions in a strict sense. ${ }^{85}$ Furthermore, case-law from the HR Commission and the Strasbourg Court supports that competition law fines are of a deterrent nature. It is clear that the HR Commission in Stenuit considered that a French law which provided for a fine amounting to $5 \%$ of the annual turnover was strongly indicative of a deterrent purpose and that the fine was of a criminal nature. ${ }^{86}$ Furthermore, the Strasbourg Court did very recently $A$ Menarini Diagnostics S. R. L. v Italy ${ }^{87}$ confirm that fines provided for in Italian law for competition law infringements were both deterrent and punitive in purpose. The imposed fine of 6 MEUR was also deterrent in practice. $^{88}$

The final argument, however, seem to conflate the concept of criminal sanctions in Article 83(2) TFEU with the concept of 'criminal charge' in Article 6 ECHR. While it is true that competition law fines may have such a deterrent and punitive purpose that it is to be considered as a criminal charge under the Convention, this does not make it a 'criminal' sanctions under Article 83(2) TFEU. Given the

\footnotetext{
${ }^{81}$ See Case T-1/89, Rhône-Poulenc SA v. Commission, [1991] ECR II-867, Opinion of Advocate General Vesterdorf, 885 .

${ }^{82}$ See A. Scordamaglia, 'Cartel Proof, Imputation and Sanctioning in European Competition Law: Reconciling effective enforcement and adequate protection of procedural Guarantees', 7(1) CLR 5, at pp. 34-35, 50 (2010); Case C-289/04 P, Showa Denko v Commission, [2006] ECR I-5859, para 57; Case C-308/04 P, SGL Carbon v Commission, [2006] ECR I-5977, para 32; See Case C-32/95, P Commission v Lisrestal [1996] ECR I-5373; Flattery, supra note 75, at p. 74

${ }^{83}$ See C-41/69, Chemiefarma v Commission, [1970] ECR 661, para. 173; C-45/69, Boehringer Mannheim v Commission, [1970] 769, para. 53; See Scordamaglia, supra note 82, at p. 13.

${ }^{84}$ See the fine of EUR 1.06 billion imposed on Intel for Article $102 \mathrm{TFEU}$ infringement (COMP/C-3 /37.990 Intel, http://ec.europa.eu/competition/sectors/ICT/intel.html.). See also the individual fine on E896 million (against Saint-Gobain in the so-called Carglass cartel). See Cartel statistics,http://ec.europa.eu/competition/cartels/statistics/ statistics.pdf.

${ }^{85}$ SeeC- 273/90, Meico-Fell v Hauptzollamt Darmstadt, supra note 25,, Opinion of AG Van Gerven para. 10.

${ }^{86}$ See HR Commission decision of 27 February 1992, in Société Stenuit v. France, A/232-A, paras. 62-64.

${ }^{87}$ See A Menarini Diagnostics S. R. L. v Italy, judgment of 27 September 2011,application no43509/08.

${ }^{88}$ Ibid., paras. 39-44.
} 
Strasbourg Court's judicial policy of avoiding decriminalisation and a loss of procedural guarantees, this case-law cannot give any serious guidance nature when deciding upon the classification under Article 83(2) TFEU. It is argued that the main criteria for deciding upon the classification, severity of the sanctions and its capacity to express moral condemnation, actually argue against a 'criminal' classification.

\section{dd) The severity of the sanctions}

There is clearly a distinction between the deterrent and punitive purpose of the sanction and their actual severity. In this regard, I tend to disagree with commentators that the severe nature of competition law fines makes them deterrent in practice. ${ }^{89}$ First, although it is true that the fines imposed under Regulation 1/2003 have a deterrent purpose, it seems that the size of the fines would not make them a deterrent penalty. Instead, it is proposed that the fines of the current size in Regulation 1/2003 cannot act as an effective deterrent for firms when contemplating to breach Union competition rules. The fact that there is a $10 \%$ limit on the annual turnover in Article 23 of the Regulation is clearly an argument in favour of considering such fines as not being of a criminal law nature. This is particularly so given the fact that the optimal fines necessary to deter firms from engaging in anticompetitive behaviour is not feasible to impose under the Regulation. ${ }^{90}$ If one assumes that firms are rational, they will make a cost-benefit analysis of the potential profits from engaging in anti-competitive behaviour weighted against the risk of detection and punishment. Given that the profits discounted by the probability of detection and conviction clearly exceed the cost of $10 \%$ ceiling of the annual profit, it seems unlikely that the fines imposed by Regulation $1 / 2003$ will be de facto deterrent. $^{91}$

\section{ee) Social-ethical labelling and principles of guilt}

The other main objection against considering fines under Regulation 1/2003 as 'criminal sanctions', is that they are unable to unequivocally express ethical-social censure. While the Court of Justice has conceded that the principle of personal responsibility has to be respected in the law of antitrust fines, ${ }^{92} 93$ and accepted that given the nature of the competition law infringements and the nature and degree of

\footnotetext{
${ }^{89}$ See Schroth, supra n 59, at p. 3, 31-40; Harding,supra n 17, 79-95.

${ }^{90}$ See Whelan, supra $n$ 64, at pp. 25-27; See W. P.J. Wils, The Optimal Enforcement of EC Antitrust law, (Kluwer Law International, 2002), 202-206;B. Rodger, 'Sanctions and deterrence in UK Competition law', in Competition law sanctioning in the European Union, (edited by G. Dannecker, and O. Jansen, (Kluwer Law International, 2004), at pp. 123-124.

${ }^{91}$ See Whelan, supra note 64, 25-27

${ }^{2}$ Case C-97/08 P, Akzo Nobel and Others $v$ Commission, [2009] ECR I-8237, para. 56; Judgment of the Court (First Chamber) of 20 January 2011, Case C-90/09 P, General Quimica and Others v Commission,[2011] ECR I-00001, para. 36; See S. Thomas, 'Guilty of a Fault that one has not Committed. The Limits of the Group-Based Sanction Policy Carried out by the Commission and the European Courts in EU-Antitrust Law', 3(1)Journal of European Competition Law \& Practice 15, (2012).

${ }^{93}$ See Thomas, supra note 92, at p. 16.
} 
severity of the ensuing penalties, the principle of the presumption of innocence applies to the procedures relating to the undertakings' infringements of the EU competition rules, ${ }^{94}$ it is questionable whether a penalty against a legal entity is ever able to express social censure. Since administrative fines under the Regulation can only be imposed on legal entities, it becomes difficult to ascribe moral responsibility to an individual. ${ }^{95}$ Since they are imposed against undertakings and not on the individuals responsible for the infringements, they do not convey stigma. It is proposed that only individual sanctions are able to communicate serious social stigma. Imposing criminal liability on fictional entities seems insufficient to express moral stigma, and this response may decrease the criminal label's effect for other types of crimes. Legal persons are abstract and impersonal entities, and as such they cannot be subject to the moral stigma associated with criminal sanctions. ${ }^{96}$

Secondly, administrative competition law fines are arguably not of such a severe nature that they can express moral condemnation. Even if the general public may consider that cartel infringements are harmful and condemnable behaviours, it is unlikely that administrative fines imposed under the Regulation communicates social stigma. ${ }^{97}$ In the first place, this is because the ceiling in the Regulation is too low to express a serious moral-social stigma. Fines are only a business cost which firms have to assume in order to pursue business. ${ }^{98}$ Fines cannot be considered as a criminal sanction because the public does not believe that fines are sufficiently expressive of condemnation. Fines do have a meaning that is sufficiently concrete, sufficiently widespread, and sufficiently at odds with appropriate condemnation, to rule them out as a 'criminal' sanction. What makes fines, when viewed as mere prices, unacceptable is that they fail to impose the condemnation that the offender deserves, however much disutility they impose. ${ }^{99}$ In the light of this, it appears that administrative fines lack sufficient moral condemnation to be characterised as a 'criminal' sanction.

\section{ff) Summary of the discussion}

Even though there are several arguments in favour of considering competition law fines as 'criminal' sanctions, including the deterrent purpose of the sanctions and

\footnotetext{
${ }^{94}$ See Case C-199/92 Hüls v the Commission,[1999] ECR p. I-4287, para. 150. This assumption is further underpinned by the Charter of Fundamental Rights where, in Articles 48 and 49, it is now explicitly stipulated that any penal sanctions require the personal responsibility of the perpetrator. That this is also applies to legal persons seems obvious from the wording of Article 48 of the Charter

${ }^{95}$ See Asp, supra note 4, at p. 395.

${ }^{96}$ Kadish, supra note 2, at p. 434; V. S. Khanna, 'Corporate Criminal Liability: What Purpose Does it Serve?'109 HARV. L. REV. 1477, at p. 1531; J S Baker Jr., 'Reforming Corporations Through Threats of Federal Prosecution' 89 Cornell L. Rev. 310, p. 334,350. (2004).

${ }^{97}$ See Whelan, supra note 64, pp. 29-30; See D. J Newman, 'White Collar Crime' 23 Law and Contemporary Problems 735, at pp. 738-739, (1958).

${ }^{98}$ See Whelan, supra note 64, at pp. 21-22; See P. Robinson, 'The Criminal-Civil Distinction and the Utility of Desert',76 B. U. L. Rev. 201, at pp. 212-13,(1996) ; D. M. Kahan, 'Social Meaning and the Economic Analysis of Crime' 27 J. Legal Stud. 609, p. 619, (1998); M. V. Hristova,'The Case for Insider-Trading Criminalization and Sentencing Reform,'13 Tenn. J. Bus. L. 267 , at p. 302, (2012).

${ }^{99}$ See Kahan, supra n 8, pp. 620-624.
} 
the need to ensure procedural rights to the defendant undertaking, it would seem, however that those arguments are insufficient to classify administrative fines as 'criminal' sanctions for the purposes of EU law. There are two interrelated reasons for this, which was accounted for above. First, the sizes of the sanctions are not high enough to be deterrent in practice. Secondly, fines do not express a social-ethical condemnation of the infringement of the competition rules. The lack of moral condemnation is caused by the low level of fines and the fact the general public do not consider fines as a sanction expressing social stigma.

\section{b) Individual administrative fines and disqualification orders}

First, it should be recognised that there is no room here for an extensive discussion on the legal nature of individual administrative fines and disqualification orders. Nevertheless, a few simple points can be made.

It is claimed that neither disqualification orders nor administrative fines against individuals can be considered as 'criminal sanctions' in EU law according to the proposed criteria. The reasons for this are the following. First, as a rule, they are not sufficiently deterrent in nature. ${ }^{100}$ The difficulty of preventing firms from indemnifying their employees for any cartel fines helps ensure that individual fines are not effective even when it is the firm's employees that are facing the formal financial sanction. ${ }^{101}$ The problem with a disqualification order is that they cannot normally be imposed against middle-managers but only directors. Furthermore, there is a risk that firms reimburse individuals close to retirement. Thirdly, although disqualification orders should in theory prevent ex-directors from becoming a de facto or shadow director, practice seems to suggest that this is not always the case. The effectiveness of disqualification orders is further weakened by the fact that the order does not preclude a convicted director from serving as a paid consultant, joining a partnership or working as an ordinary employee or having a spouse replacing the convicted director in the board. ${ }^{102}$

Secondly, neither disqualification orders nor fines express, as a rule, sufficient moral condemnation to classify as 'criminal' sanctions. Admittedly, it is true that disqualification orders and individual fines may express a serious moral condemnation if their imposition is linked to the finding of guilt, linked to the imposition of a criminal record or linked to commission of a criminal offence. ${ }^{103}$ In such cases, it seems that they must be considered as 'criminal' sanctions for the purposes of Article 83 (2) TFEU. Nevertheless, if this is not the case, it appears that these quasi-criminal sanctions fulfil the high standards identified for being considered as 'criminal' sanctions.

\footnotetext{
${ }^{100}$ See J. Gobert \& M. Punch, Rethinking Corporate Crime (Butterworths, 2003), pp. 273, 275, 279.

${ }^{101}$ See Whelan, supra note 64, at p. 32; A. L Liman, 'The Paper Label Sentences: A Critique' 86 The Yale Law Journal 619, at pp. 630-633, (1977); Wils,supra note 44, at pp. 37-38.

102 See Gobert and Punch,supra note 100, at p. 279; Wils, supra note 44, at pp. 38-39; See Kahan,supra note 8, at pp. 620-24.

103 See Reform of the Federal Criminal Laws: Hearing Before the Subcomm. on Criminal Laws and Procedures of the Senate Comm. on the Judiciary, 92 d Cong., 1st Sess. 1788 (1972) (statement of the National Assoc. of Manufacturers), 1651, 1654.
} 
The community's moral judgment over the imposition of fines or disqualification orders is not that those sanctions communicate stigma. In relation to fines, it was stated above that they often convey the normative message that society is willing to accept the offender's behaviour. ${ }^{104}$ Fines fail to impose the censure that the offender deserves. By viewing fines as mere prices for committing an offence, the seriousness of the offence is belittled and it defiles the victims of the crime. ${ }^{105}$

A disqualification order is, nevertheless, a slightly complex issue since it expresses some condemnation, as it has a deterrent and punitive purpose and causes serious hardship for individuals. ${ }^{106}$ If a disqualification order were to be used as an alternative to imprisonment and be combined with a small term of imprisonment it would convey a different meaning and express such serious moral condemnation and entail such severe consequences for individuals that it would be tantamount to a 'criminal sanction'. ${ }^{107}$ It can, however, be plausibly argued that disqualification orders, as a rule, do not carry the same social stigma as an imprisonment sanction which is the prime example of 'criminal' sanctions. ${ }^{108}$ Due to the value attached to liberty in contemporary society, imprisonment does arguably convey stronger denunciation of wrongdoers than disqualification orders. ${ }^{109}$ Unless disqualification orders are linked to the commission of a 'criminal' offence or unless they are combined with probation or conditional prison sentences, they fail to express serious moral condemnation. Furthermore, suggesting that disqualification orders must be combined with conditional sentences or imprisonment logically entails the proposition that 'disqualification orders' per se do not communicate sufficient social censure to be characterized as a criminal sanction. ${ }^{110}$ Given that the core question of the article is about deciding whether a 'disqualification' order is a 'criminal' sanction, it seems probable that 'disqualification' would not, as a rule, fit into this category. $^{111}$

Nevertheless, even though it has been shown that a disqualification order and individual administrative fines cannot be adopted under Article 83(2) TFEU, it is important to recall that non-criminal sanctions can be adopted under other legal bases of the Treaties. Rules requiring criminalization of less serious infringements can be adopted on the basis of the general competences in the Treaty. For example, the EU may, without invoking the criminal law competence provided for in Article 83 (2) TFEU, in a directive require the Member States to ensure that infringements of the provisions of a directive are punished by penalties that are 'effective, proportionate and dissuasive'. The Union has the competence to require that the Member States protect the interests of the Union in an effective way as long as the Union

\footnotetext{
${ }^{104}$ See Kahan, supra note 8, at p. 593, 650.

105 See e. g. Tadros, supra note 64, at p. 165; Kahan, supra note 8, at p. 620; See Hristova, supra note 98, p. 302.

${ }^{106}$ M. F. McDermott, 'Occupational Disqualification of Corporate Executives: An Innovative Condition of Probation', 73 J. Crim. L. \& Criminology 604, pp. 615-618, (1982).

${ }^{107} \mathrm{Ibid}$, at pp. 615-617, 620-621, 641.

${ }^{108}$ See Kahan's argument, supra note 8, at pp. p. 599, 603, 617, 621. .

${ }^{109}$ See e. g. Whelan, supra note 64, at p. 37; Wils, supra note 44, at pp. 38-39

${ }^{110}$ See e. g. Wils, supra note 90, at p 222; Gobert and Punch, supra note 100, at p. 279.

${ }^{111}$ See Gobert and Punch, supra note 100, at pp. 273, 275, 279.
} 
does not specifically require criminal law sanctions. ${ }^{112}$ To the extent that the Union has competence to regulate a certain area, as is the case with the environment or agriculture, it can be assumed that this also involves competence relating to administrative penalties in connection with the area in question. ${ }^{113}$ The Union legislature has, according to settled case-law, discretion as to the method of approximation which is the most appropriate in order to improve the conditions for the establishment and proper functioning of the Internal Market. This includes a competence to harmonize national laws concerning the type and level of administrative sanctions to be imposed. ${ }^{114}$ This power arguably encompassed serious sanctions such as disqualification orders or individual fines. ${ }^{115}$

\section{c) Effective, proportionate and dissuasive criminal penalties- applica- tion of the criteria in relation to Union criminal law directives and Article 83(2) TFEU}

What does the application of the criteria for 'criminal' sanctions mean for the Member States when they have to implement 'criminal penalties'?

The issue here is that several directives in the field of Union criminal law do not prescribe the type and level of criminal penalties. As an example, the Environmental Crime Directive, the Market Abuse Crime Proposal, and the Ship Pollution Crime Directive only require that Member States impose criminal sanctions/penalties that are 'effective, proportionate, and dissuasive'. ${ }^{116}$ Member States thus have certain discretion to decide what criminal sanctions should be imposed in the case of infringements of the criminal offences of the directive. The implementation of a directive on criminal law measures becomes relevant when the Commission and the Court of Justice shall decide on whether the Member State has complied with their obligations under the Directive. If the Union do not specify the penalty and only says that it should be a 'proportionate, effective and dissuasive' criminal sanction, it surely becomes difficult for the Commission and the Court of Justice to determine whether the Member State has complied with their obligations under the Directive.

\footnotetext{
${ }^{112}$ See Asp, supra note 6, at p. 32, 86.

113 See Haekkerup,supra note 33, at p. 162, 168.

${ }^{114}$ See COMMISSION STAFF WORKING PAPER, IMPACT ASSESSMENT Accompanying document to the COMMUNICATION FROM THE COMMISSION TO THE EUROPEAN PARLIAMENT, THE COUNCIL, THE EUROPEAN ECONOMIC AND SOCIAL COMMITTEE AND THE COMMITTEE OF THE REGIONS, 'Reinforcing sanctioning regimes in the financial services sector', at p. 21. SEC(2010) 1496 final, Brussels, 8. 12. 2010; Case 58/08, Vodafone, [2010] ECR I-04999, para. 35; Case C-217/04,United Kingdom vParliament and Council [2006] ECR I-3771, para. 43.

${ }^{115}$ See Article 26 (h) and 26(l) of Proposal for a REGULATION OF THE EUROPEAN PARLIAMENT AND OF THE COUNCIL on insider dealing and market manipulation (market abuse), Brussels, 20. 10. 2011 COM (2011) 651 final, 2011/0295 (COD), at pp. 4, 15, 48.

${ }^{116}$ See Article 5 of DIRECTIVE 2008/99/EC OF THE EUROPEAN PARLIAMENT AND OF THE COUNCILof 19 November 2008 on the protection of the environment through criminal law; Article 1 of amended DIRECTIVE 2009/123/EC OF THE EUROPEAN PARLIAMENT AND OF THE COUNCIL of 21 October 2009 amending Directive 2005/35/EC on ship-source pollution and on the introduction of penalties for infringements; Article 6 of Proposal for a DIRECTIVE OF THE EUROPEAN PARLIAMENT AND OF THE COUNCIL on criminal sanctions for insider dealing and market manipulation, COM(2011) 654 final. The formula can be derived from the case-law of the Court of Justice: C-68/88, Commission v Greece, [1989] ECR 2965, para. 24.
} 
Let us assume that one Member State $(\mathrm{X})$ imposes a payable fine and another Member State $(\mathrm{Y})$ imposes a jail sentence when implementing the Environmental Crime Directive.

It seems obvious that Member State $\mathrm{Y}$ has complied with the Directive as imprisonment, according to the proposed definition, is a 'criminal' sanction. Whether Member State X has complied with the Directive is less clear. Depending on the severity of the fine and whether it is imposed in a criminal or administrative proceeding and whether it is linked to a criminal offence, it may be either 'criminal' or non-criminal according to the proposed criteria. It can, however, be reasonably argued that there should be some scope for the Member States when implementing these sanctions. The relevant issue for the Court to decide is whether the Member State has implemented a 'criminal sanction'. Unless it is a 'criminal sanction' according to the proposed criteria, they have breached their obligations under the Directive. Secondly, if it is a 'criminal sanction', it should also fulfil the criteria of being 'dissuasive, proportionate and effective'. Those requirements are vague and their concrete meaning in EU law is unclear. ${ }^{117}$

Are criminal fines more proportionate than jail sentences? ${ }^{118}$ The criteria of 'effectiveness' and 'dissuasiveness' are also potentially in conflict with the proportionality criteria. It is quite obvious that jail sentences can be effective in the sense that they are dissuasive and are more apt to achieve the goals of the Union legislator than without the threat of such a sanction. ${ }^{119}$ Maximum or full compliance with a certain rule can perhaps be achieved by means of a very harsh penalty, for example, life time imprisonment for a minor offence of selling two protected specimens of wild flora. Such a penalty would however not be 'proportionate' given that it would be completely excessive to the gravity of the offence and given that it would be possible to achieve compliance with the rules on the selling of fauna with less restrictive measures, e.g. criminal fines. It is therefore perfectly possible that a sanction is 'proportionate' to the harm/danger and culpability of an offence without being a fully 'effective' and 'dissuasive' sanction. ${ }^{120}$

As demonstrated by this example, the Commission's practice seems to be somewhat questionable. It gives rise to uncertainty as most Member States cannot ascertain what is meant by 'dissuasive, proportionate and effective' criminal penalties. Furthermore, it becomes more difficult to achieve uniformity in the application of Union law which presumably is one of the reasons why the Union adopts harmonization measures. It seems more appropriate to simply prescribe that Member States should implement 'criminal penalties'. The practice of only requiring the

\footnotetext{
${ }^{117}$ See M. Faure, 'Effective, Proportional and Dissuasive Penalties in the Implementation of the Environmental Crime and Ship-source Pollution Directives: Questions and Challenges', 19(6) European Environmental Law Review 256, at p. 256, 277 (2010).

118 Ibid, at p. 266.

119 Ibid, at pp. 260-64.

${ }^{120}$ See Communication from the Commission to the European Parliament, the Council, the European Economic and Social Committee and the committee of the Regions, - 'Towards an EU Criminal Policy: Ensuring the effective implementation of EU policies through criminal law', Brussels, 20. 9. 2011 COM(2011) 573 final, 9, 11; Faure, supra note 117 , at pp. $264-65$.
} 
adoption of a 'criminal' penalty would reduce the risk of unnecessary litigation over the indeterminate meaning of 'dissuasive, effective and proportionate' criminal penalties. ${ }^{121}$ It is also being argued that the assessment whether a criminal sanction is 'dissuasive, effective and proportionate' should be done by the Union legislator and not by the Member States. This assessment can be done initially when the Union legislator considers whether criminal sanctions are 'essential' for the effective implementation of Union policies within the meaning of Article 83(2) TFEU.

Despite the above criticism, it seems difficult to claim that the Union legislator is breaching Article 83(2) TFEU only because they fail to specify the 'criminal' sanction. The relevant question is, of course, whether the Environmental Crime Directive, the Market Abuse Crime Proposal and the Ship Pollution Crime Directive imply that the Union, strictly speaking, has adopted a 'criminal' sanction? In my opinion, the answer would be negative as there is no specification of the penalty in these measures. As has been argued above, the labelling of something as a 'criminal offence' does not necessarily mean that the sanction that follows will necessarily be criminal, and the specification in the Directive of 'effective, proportionate and dissuasive criminal penalties' is not conclusive in stating that the Directive imposes a criminal sanction either. The Union legislator has no obligation under Article 83 (2) TFEU to provide for specified criminal penalties simply because they decide to criminalize an offence. The practice of not specifying the criminal penalty could also be defended on subsidiarity grounds as it gives more freedom to Member States to adopt an appropriate criminal penalty. In some cases 'criminal fines' may be sufficient and in other cases it may be necessary to impose 'imprisonment sentences'. ${ }^{122}$

As illustrated by this example, the proposed criteria will give the Union institutions a solid basis for ascertaining which sanctions they can adopt on the basis of Article 83 (2) TFEU. The proposed definition will also assist the Commission, the Member States and the Court of Justice in ascertaining whether the Member States have complied with their obligations in Directives to impose criminal sanctions. By employing this definition, the Union institutions will be able to safeguard the uniform application of criminal sanctions in the national legal orders.

\section{Conclusions}

The article set out to discuss the concept of 'criminal' sanctions in EU law. The first part of the article discussed the function and purposes of the concept of criminal sanctions in EU law. It was demonstrated that there are two concepts of 'criminal sanctions' in EU law which fulfil different functions. First, there is a concept in matters of competences which applies in relation to the scope of Article 83(2) TFEU and the Member States' obligation to implement EU law. In order to clarify

\footnotetext{
${ }^{121}$ See Faure, supra note 117, at pp. 275, 278.

${ }^{122}$ See Faure, supra note 117, at p. 275, 78; Case 440/05, Commission v Council, supra note 31, paras. 69-70
} 
the scope of Member States' obligations under EU criminal law directives and in order to ensure that EU powers are not used excessively, this must be a narrow concept. It was further argued that the interest of not 'diluting' the moral element of the 'criminal sanction' and the need to maintain the legitimacy of criminal law, called for having a narrow definition of criminal sanction. Secondly, there is a concept of 'criminal' sanctions in EU law for the purposes of determining the scope of procedural guarantees. In order to ensure that the EU do not decriminalize offences and impose severe sanctions without sufficient procedural guarantees, this concept must be a wide one. The consequences of having two different concepts is that the EU can adopt sanctions which are not 'criminal' for the purposes of Article 83 (2) TFEU, under for example Article 114 TFEU, but are considered as 'criminal charges' for the purposes of fundamental rights protection requiring that the EU and Member States ensure all procedural guarantees for the imposition of such sanctions.

The second part of the article showed that the concept of criminal sanctions under Article 83(2) TFEU includes the following features:

(i) a prescription that the behaviour is criminal (formal classification),

(ii) the nature of the proceedings,

(iii) that the sanctions are imposed after a finding of guilt,

(iv) the deterrent and punitive purpose of the sanctions,

(v) the severe nature of the sanction,

(vi) whether the sanction expresses a moral condemnation.

The third part of the article discussed the specific application of the concept. The proposed definition was applied to the case of competition law fines, disqualification orders and administrative fines against individuals. Even though there were several arguments in favour of considering competition law fines against undertakings as 'criminal' sanctions, including the deterrent purpose of the sanctions, and the need to ensure procedural rights to the defendant undertaking, it was, however, contended that those arguments were insufficient to classify competition law fines as 'criminal sanctions' for the purposes of EU law. There were two interrelated reasons for this. First, the sizes of the sanctions are neither high enough nor otherwise sufficiently dissuasive to be deterrent in practice. Secondly, competition law fines do not express sufficient social-ethical condemnation of the infringement of the competition rules to be characterised as 'criminal' sanctions.

In terms of disqualification orders and individual administrative fines, it was argued that as a general rule they would not be considered as 'criminal sanctions' in EU law. First, they are not, as a rule, dissuasive in practice. Secondly, they fail to express serious moral condemnation. Nevertheless, in some cases, where the individual fine or the disqualification order is linked to the commission of a criminal offence and entails a criminal record, it could be considered as a 'criminal sanction'.

Finally, the article discussed whether the Union when adopting the Environmental Crime Directive, the Market Abuse Crime Proposal or the Ship Pollution Crime Directive, strictly speaking adopted a 'criminal sanction' according to the proposed 
criteria. It was proposed that the lack of specification of the penalty meant that the Commission in fact failed to adopt a 'criminal' sanction. The Union legislator did neither breach EU law by not specifying the penalty since there is no requirement in the first place under Article 83(2) TFEU to specify the penalty. Giving discretion to Member States to determine the type and level of the penalty is also consistent with the principle of subsidiarity. 